\title{
Application of Project Teaching Method in Three-dimensional Animation Teaching
}

\author{
Xiaojun Zhou \\ Department of Fine Arts and Design, Dongchang College, Liaocheng University, Shandong, China, \\ 252000
}

Keywords: Three-dimensional animation; teaching; project

\begin{abstract}
Project teaching method is based on the project as a carrier to carry out teaching, and integrate theoretical knowledge into the project, so as to successfully solve the project problems and realize the practical transformation of the knowledge learned. The teaching of three-dimensional animation in colleges and universities has higher requirements for characteristically ability and innovative quality, while the traditional teaching methods can no longer meet the needs of three-dimensional animation teaching in colleges and universities. This paper introduces the project teaching method into the three-dimensional animation teaching in colleges and universities, and puts forward the concrete implementation steps of the project teaching method, that is, defining the project-selecting scheme-setting up group-teaching evaluation, in order to provide reference for the application of the project teaching method in the course teaching.
\end{abstract}

Three-dimensional animation involves film and television special effects creativity, ore-shooting, film and television 3D animation, special effects post-synthesis, film and television drama special effects animation and so on. It is a practical subject. For students, if they want to improve their subject quality in an all-round way, they must deeply participate in teaching practice, improve their practical ability and production ability in practice, and realize the improvement of innovation quality and aesthetic ability. The project teaching method conforms to the characteristics of three-dimensional animation teaching in Colleges and universities, and it has very important value and significance in three-dimensional animation teaching.

\section{The Connotation and Basic Characteristics of Project Teaching Method}

Project teaching method advocates the project as the carrier to carry out teaching, integrating theoretical knowledge into the project, so as to successfully solve the project problems, at the same time, realize the practical transformation of the knowledge learned. Project teaching method has a strong systematic. It realizes the promotion and shaping of studentship-round quality, and plays an important role in the promotion of individual theoretical knowledge, professional accomplishment, reaction ability, cooperation ability and innovation quality. It conforms to the goal and mission of quality education reform. In teaching practice, teachers can decompose classroom knowledge into several specific projects, and students can independently complete project design, theoretical knowledge extension, team discussion, process evaluation and so on, so as to improve the overall 
quality of students.

Project teaching method has the following basic characteristics. As shown in figure 1.

The multiplicity of target orientation

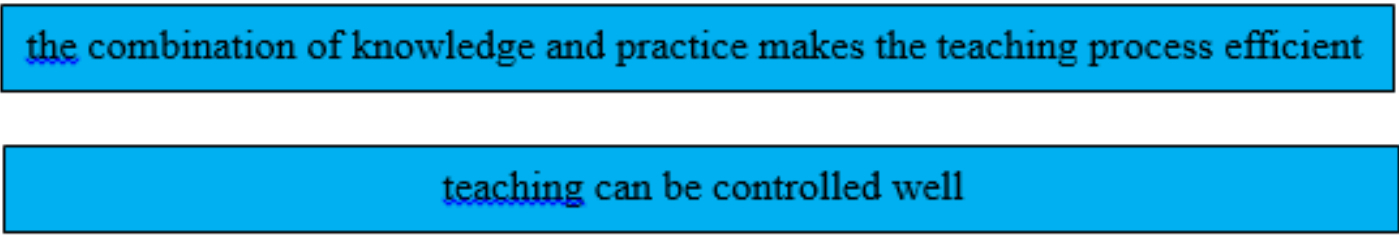

Figure 1. The basic characteristics of Project teaching method

First, the multiplicity of target orientation. In the process of professional teaching in traditional colleges and universities, the teaching objectives are often single, and it is basically impossible to achieve multiple shaping of students in classroom teaching. Project-based teaching breaks through this limitation. In the process of project-based teaching, studentship ability, self-learning ability, creativity, teamwork ability and other abilities can be maximized, and students' multiple abilities can be realized. Three-dimensional shaping. Second, the combination of knowledge and practice makes the teaching process efficient. Applying project teaching method to college teaching, semiprofessional theoretical knowledge can be practiced and verified in the project. This process can realize the close combination of theory and practice, help to transform students' professional theoretical knowledge into practical ability, and ensure the high efficiency of teaching process. Thirdly, teaching can be controlled well. In the process of project teaching, students are the main body of the teaching process, while teachers are the guide of the teaching process. Teachers and students participate in the teaching practice together, which helps teachers adjust the teaching progress flexibly and improve the teaching effect.

\section{The Significance of Applying Project Teaching Method to Three-dimensional Animation Teaching in Colleges and Universities}

Firstly, it can effectively improve the denuclearizing enthusiasm. Project-based teaching method takes specific projects as the center, introduces various practical life cases in boring theoretical learning, and extends skills learning to specific application fields, which can effectively stimulate enthusiastically for learning and improve teaching effectiveness. Secondly, it can combine theory teaching with practice teaching. The practice of three-dimensional animation teaching in Colleges and universities is strong, which requires students to strengthen practical training on the basis of learning theoretical knowledge. The introduction of project teaching method into three-dimensional animation teaching can ensure the effective connection between classroom learning and practical teaching, promote the transformation of acknowledgement to practical skills, and then maximize the teaching effect and efficiency. Finally, it is helpful to cultivate understatement spirit. The project of three-dimensional animation teaching needs students to form a group to complete. In the process of project implementation, students compete with each other, cooperate with each other, and gradually establish team consciousness and competitive consciousness, laying a solid foundation for future learning.

\section{Problems of Project Teaching Method in the Course of Three-dimensional Animation Short Film Design}

There are some problems in the application of project-based teaching method in the design of 
three-dimensional animation short films, so that animation short films can not be better presented to people, so we must understand the problems in the design of three-dimensional animation short films. As shown in figure 2.

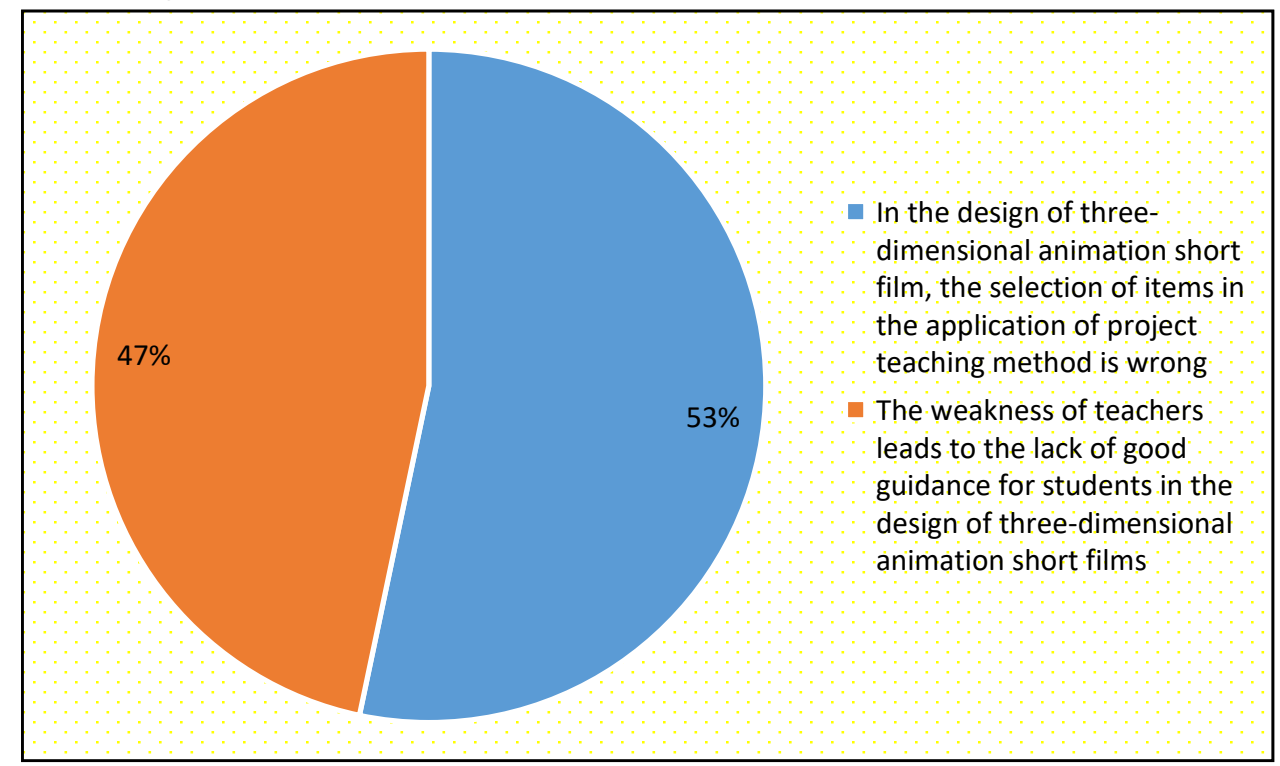

Figure 2.Problems of Project Teaching Method in the Course of Three-dimensional Animation Short Film Design

3.1 In the design of three-dimensional animation short film, the selection of items in the application of project teaching method is wrong

For the design of three-dimensional animated short films, since the project teaching method is used, teachers must choose the right project to teach students and design three-dimensional animated short films. However, in order to improve the speed of denuclearizing the design of three-dimensional animated short films, many schools often choose wrong projects for students. These projects are either very difficult for students to learn the design of three-dimensional animated short films, or too simple to show students' abilities, which are not based on the analysis of institutionalization.

\subsection{The weakness of teachers leads to the lack of good guidance for students in the design of three-dimensional animation short films}

In the design of three-dimensional animation short film, the most important thing for the application of project teaching method is the guidance and help of teachers. For the design aspect, the weakness of teachers makes students not have a good guidance in learning the design of three-dimensional animation short film, so that students can not better understand and master the animation short film. Therefore, without inspiration in the design, they can not design it. Better works.

\section{The Practical Thought of Project Teaching Method in the Teaching of Three-dimensional Animation in Colleges and Universities}

The teaching of three-dimensional animation project in Colleges and universities is a systematic and systematic process. In practice, it should be carried out in the order of defining the 
project-selecting scheme-setting up group-teaching evaluation so as to ensure the orderly development of each link. Now we will focus on these four aspects of in-depth elaboration and analysis.

\subsection{Define teaching objectives and determine reasonable teaching projects}

Determining the teaching project of three-dimensional animation is an important prerequisite for carrying out teaching. Firstly, we must determine the teaching project according to the teaching goal of three-dimensional animation in Colleges and universities, clarify the abilities and qualities that need to be cultivated in the teaching process, and reasonably select the project content, so as to ensure the accuracy and pertinence of the project content. Secondly, in the process of teaching three-dimensional animation in Colleges and universities, we should fully guide students to participate in it and enhance their enthusiasm for learning. For example, project selection can be carried out in the form of video clips and evaluation criteria matching with them can be determined. In this way, students can choose appropriate projects according to their interests and specialties, and give full play to their artistic ability and innovative ability. Thirdly, when choosing three-dimensional animation teaching projects, colleges and universities should also integrate the development goals of professionalization with the development trend of the current art industry and professional needs to select projects of practical significance in order to ensure the integration of project teaching and social development.

\subsection{Develop project plan to ensure the scientific nature of project teaching}

After determining the teaching project, colleges and universities should formulate reasonable project plans according to the teaching situation, so as to promote the smooth development of project teaching. The project practice plan needs to be agreed by both teachers and students. Teachers also need to evaluate instabilities and make project implementation plans for students in order to ensure the improvement of students' abilities and the enhancement of their qualities. In short, there is no unified standard for the teaching of three-dimensional animation in Colleges and universities, but a comprehensive formulation of the project plan should be combined with the elements of learning content, instabilities, project objectives and so on, so as to promote the implementation and development of follow-up projects.

\subsection{Establishment of project teams to clarify the division of tasks}

Three-dimensional animation project teaching in Colleges and universities requires students to form a team to participate in. Therefore, it is necessary to establish a project cooperation group to ensure the realization of teaching activities, and on this basis to carry out task division to ensure the smooth implementation of the project plan. Firstly, according to the specialties, personality and learning situation, it is rationalized to group them, so as to ensure that the members of each group have hierarchical competence and achieve a balanced staffing. Generally speaking, four to six students are selected as a group, and according to their abilities, they are given corresponding roles and work contents, so that they can cooperate closely and complement each other. Secondly, the project content is decomposed into specific activities and allocated to each student to improve the curability of the three-dimensional animation project.

\section{Conclusion}

Animation project needs knowledge of many disciplines and professional courses. It breaks the 
barriers between courses and helps students integrate various knowledge. Students participate in the implementation process of the project, which stimulates the initiative and creativity of learning. At the same time, the implementation of the project requires the cooperation and communication of the whole team members, which exercises the team spirit and communication ability of students, and creates conditions for the realization of zero-distance integration with enterprises. In a word, project teaching method is an effective way to achieve "work-study integration" in animation production and other applied and comprehensive courses, and should be vigorously promoted in Vocational colleges.

\section{References}

[1] Bu Huey. Exploring the Application of Project Teaching Method in Animation Teaching in Applied Universities [J]. Journal of Jilin Institute of Education: Mid-term, 2012, (5): 19-20.

[2] Bhang H. Brief Analysis of the Application of Project Teaching Method in the Teaching of "Three-dimensional Foundation" Course in Colleges and Universities [J]. Journal of Amusing College of Education, 2012, (5): 132-133.

[3] Du Song. The Practice and Research of "Project Teaching Method" in Three-dimensional Animation Teaching in Higher Vocational Education [J]. China's Out-of-School Education, 2012, (27): 119.

[4] Li Shijiazhuang. Practice and Research in the Teaching of 3D Animation Short Films Based on Project Teaching Method [J]. Electronic Production, 2014, (21): 104.

[5] Mia Jinnah, Fao Puling. Practice of Project Teaching Method in Two-Dimensional Animation Course --- Take An yuan Boy, School of Science and Technology, Nanchang University as an example [J]. Journal of Tianjin Chino-German Vocational and Technical College, 2014, (3): 31-33. 